\title{
Pengembangan Paket Pelatihan Bimbingan Dengan Teknik Outbound untuk Mengembangkan Resiliensi Siswa SMP
}

\author{
Lila Puspitaningrum*, Blasius Boli Lasan, Ella Faridati Zen \\ Universitas Negeri Malang, Jl. Semarang No. 5 Malang, Jawa Timur, Indonesia \\ *Penulis korespondensi, Surel: lakalila1@gmail.com
}

Paper received: 1-4-2021; revised: 22-4-2021; accepted: 29-4-2021

\begin{abstract}
The purpose of this development research is to produce a training package for guidance with outbound techniques to develop resilience of junior high school students who meet the acceptance criteria. The steps of this development are (1) the preparation stage consisting of literature review, analysis of needs and potential problems, determining development objectives and preparing the necessary materials (2) the development stage consisting of preparing a product prototype and product design (3) the validation stage consisting of initial product testing, revision I, testing of prospective product users, revision II and final product preparation. The results showed that outbound techniques to develop resilience in junior high school students met the appropriate requirements for counseling guidance services by counselors.
\end{abstract}

Keywords: guidance; resilience; outbound techniques

\begin{abstract}
Abstrak
Tujuan penelitian pengembangan ini adalah untuk menghasilkan paket pelatihan bimbingan dengan teknik outbound untuk mengembangkan resiliensi siswa SMP yang memenuhi kriteria keberterimaan. Langkah dari pengembangan ini adalah (1) tahap persiapan yang terdiri dari kajian pustaka, analisis kebutuhan dan potensi masalah, menentukan tujuan pengembangan dan menyiapkan bahan yang diperlukan (2) tahap pengembangan terdiri dari penyusunan prototype produk dan desain produk (3) tahap validasi terdiri dari uji coba produk awal, revisi I, uji coba calon pengguna produk, revisi II dan penyusunan produk akhir. Hasil penelitian menunjukkan teknik outbound untuk mengembangkan resiliensi pada siswa SMP telah memenuhi syarat yang layak digunakan untuk layanan bimbingan konseling oleh konselor.
\end{abstract}

Kata kunci: bimbingan; resiliensi; teknik outbound

\section{Pendahuluan}

Persoalan hidup selalu dialami oleh setiap individu. Beberapa individu mampu melewati ada pula yang tidak mampu melewatinya. Persoalan individu dialami oleh semua kalangan baik orang dewasa, remaja maupun anak - anak dan membuat setiap individu merasakan situasi tidak nyaman. Situasi yang membuat tidak nyaman bisa dari luar individu misalnya pengabaian, perceraian orang tua, status ekonomi, bencana alam ataupun kehilangan seseorang yang dicintai. Sumber lain juga dapat berasal dari dalam individu, misalnya dikucilkan, merasa bersalah, kegagalan, rasa takut, atau karena diserang penyakit.

Siswa SMP berada pada usia antara 12 - 15 tahun, berarti masuk pada periode perkembangan di masa remaja awal. Pada masa itu siswa SMP tidak lepas dari persoalan hidup yang harus mereka hadapi mulai dari yang sederhana hingga yang rumit. Masa remaja merupakan masa dimana individu merasa dirinya mampu mengatasi persoalannya sendiri dan menolak bantuan dari orang tua dan guru - gurunya (Hurlock, 2003). Namun ketika individu merasa tidak mampu menghadapi persoalan dalam hidupnya akan berakibat pada perilaku 
yang negatif. Ketidakmampuan individu dalam menghadapi persoalan hidup yang terjadi akan mempengaruhi psikologis dan perilakunya yang mengarah ke hal negatif seperti frustasi, stress, depresi, penyalahgunaan narkoba dan minuman beralkohol, perbuatan kriminal hingga bunuh diri. Karena ketika dihadapkan pada persoalan, remaja cenderung menggunakan emosi dalam menghadapinya.

Selain dengan emosi, beberapa individu hanya pasrah dengan keadaan, dan beberapa lainnya akan menyalahkan orang lain bahkan Tuhan. Pada masa ini remaja sering disebut berada pada periode "badai dan tekanan", dimana emosi semakin meninggi karena perubahan fisik dan kelenjar. Individu usia remaja ingin mendapatkan pengakuan dan cenderung tidak mau menerima bantuan dari orang lain. Ketika individu tersebut tidak mampu menghadapi periode tersebut sendiri, individu akan mengalami stress dan depresi. Dalam menghadapi situasi tersebut, perlu kemampuan dari diri individu sehingga tidak membuat individu berperilaku negatif.

Namun setiap individu juga memiliki ketahanan diri dalam menghadapi hidup. Ketahanan dalam menghadapi hidup disebut resiliensi. Resiliensi adalah kemampuan individu untuk bangkit, menghadapi dan mengatasi masalah atau situasi yang tidak sesuai dengan rencananya (Reivich dan Shatte, 2002). Grothberg (1995) mengartikan resiliensi sebagai kekuatan atau daya tahan seseorang untuk menghadapi, mengatasi, menjadi lebih kuat, dan bahkan mengubah pengalaman tidak menyenangkan. Reivich dan Shatter (2002) menjelaskan beberapa kemampuan yang dapat membentuk resiliensi individu, yaitu regulasi emosi, pengendalian impuls, optimis, empati, analisiss penyebab masalah, efikasi diri dan reaching out. Reivich dan Shatter juga berpendapat bahwa hampir tidak ada satupun individu yang secara keseluruhan memiliki tujuh kemampuan tersebut dengan baik. Resiliensi menjadi kemampuan yang penting dimiliki oleh setiap individu. Resiliensi dapat menjadi kunci dari kesuksesan dan kebahagiaan seseorang. Namun tidak semua individu memiliki resiliensi yang tinggi dalam menghadapi persoalan hidup. Sehingga rendahnya Resiliensi pada diri remaja, menjadi salah satu penyebab munculnya perilaku - perilaku yang kurang sesuai.

Reivich dan Shatter (2002) secara khusus menyampaikan bahwa individu dapat meningkatkan resiliensinya. Salah satu cara meningkatkan resiliensi individu adalah dengan mengajarkan diri sendiri. Sebuah penelitian yang dilakukan Shochet dan Wurfl (2016) tentang pembangunan Resiliensi (daya pegas) untuk menjaga kesehatan mental Remaja, menunjukkan bahwa mengembangkan Resiliensi pada remaja dapat membuahkan hasil positif bagi remaja (Geldard, 2009). Penelitian ini mengembangkan program membangun resiliensi berfokus pada pembangunan kekuatan individu, dan membuahkan hasil positif bagi remaja bahkan masyarakat umum.

Bimbingan dan Konseling berperan membantu siswa menemukan cara mengatasi hambatan perkembangannya di sekolah salah satunya mengembangkan keterampilan resiliensi. Keterampilan resiliensi dapat dikembangkan melalui layanan bimbingan kelompok. Salah satu teknik yang dapat digunakan yaitu outbound. Teknik outbound menjadi pola pengembangan potensi sumber daya manusia melalui pendidikan yang terintegrasi melalui pengembangan media simulasi di alam terbuka dengan tujuan untuk memberikan ruang belajar serta pemikiran dan pemahaman yang lebih kondusif kepada siswa.

Menurut M. As'adi (2009) outbound menjadi aktivitas yang fun dan menantang. Aktivitas berupa simulasi kehidupan lewat permainan - permainan atau games yang kreatif, reaktif dan 
edukatif, baik dimainkan secara individual maupun kelompok untuk pengembangan personality. Interaksi manusia dengan alam berjalan alami akan mampu memberikan refleksi yang bermanfaat bagi pengembangan lembaga, perusahaan, maupun organisasi (Ancok, 2002)

Teknik outbound menjadi salah satu teknik bimbingan yang sesuai untuk meningkatkan personality seseorang, karena lewat permainan yang tercipta membuat suasana santai, menyenangkan, serta sesuai keinginan. Penelitian yang dilakukan oleh Lolang Mariana (2014) dengan subjek penelitian siswa SMK menunjukkan bahwa teknik outbound efektif untuk mengurangi perilaku agresif pada siswa SMK dimana siswa SMK mampu mengelola emosi yang merupakan bagian dari regulasi emosi. Regulasi emosi merupakan faktor dari resiliensi. Melalui teknik ini siswa akan dilatih mengendalikan emosi dan membuat pertahanan diri, sehingga mampu melatih siswa untuk menghadapi persoalan hidupnya. Menurut Ancok (2002) outbound merupakan suatu penambah wawasan pengetahuan yang didapat dari serangkaian pengalaman berpetualang sehingga dapat memacu semangat dan kreatifitas seseorang. Outbound dirasa efektif untuk meningkatkan kemampuan personal dari individu. Penelitian oleh Hetti dan Diana (2011) menunjukkan bahwa outbound efektif untuk meningkatkan kemampuan resolusi konflik interpersonal pada remaja.

Teknik outbound pun dirasa tepat dalam meningkatkan resiliensi siswa. Melalui kegiatan outbound siswa diberi pengetahuan tentang maksud dan tujuan permainan, termasuk metode yang digunakan dan diberikan gambaran masalah lingkungan kegiatan secara kelompok. Selama masa outbound, siswa mendapatkan pengalaman dalam permainan bersama yang kemudian mendukung munculnya resilien pada diri siswa.

Pengembangan teknik outbound untuk mengembangkan resiliensi menjadi produk penelitian yang akan dikembangkan oleh peneliti. Penelitian pengembangan ini bertujuan untuk menghasilkan paket bimbingan teknik outbound yang dapat digunakan oleh konselor dalam memberikan layanan kepada siswa untuk mengembangkan resiliensi dirinya sesuai dengan kriteria keberterimaan. Selain itu peneliti akan menghasilkan buku panduan yang akan digunakan konselor untuk memahami teknik outbound sehingga dapat melaksanakan dengan mudah dan tepatDerajat kemutakhiran bahan yang diacu dengan melihat proporsi 10 tahun terakhir dan mengacu pustaka primer. Permasalahan dan tujuan, serta kegunaan penelitian ditulis secara naratif dalam paragraf-paragraf, tidak perlu diberi subjudul khusus. Demikian pula definisi operasional, apabila dirasa perlu, juga ditulis naratif.

\section{Metode}

Penelitian pengembangan ini menggunakan rancangan penelitian dan pengembangan yang memodifikasi prosedur pengembangan model Research and Development (R\&D) Borg and Gall (1983). Pengembangan diawali dengan tahap Persiapan yang terdiri dari kajian pustaka untuk menyusun dasar teori, menganalisiss kebutuhan dan potensi masalah melalui observasi dan wawancara, menentukan tujuan pengembangan dan menyiapkan bahan yang diperlukan untuk pengembangan produk. Tahap kedua merupakan tahap pengembangan. Pada tahap ini peneliti menyusun prototype produk pengembangan dan mendesain produk. Lalu tahap ketiga adalah tahap validasi yang terdiri dari uji coba produk awal, revisi I, uji coba pengguna produk dan revisi II. Selanjutnya penyusunan produk akhir.

Lokasi penelitian pengembangan ini adalah SMP Negeri 04 Kota Batu. Subjek Penelitian awal dilakukan kepada 65 siswa dengan menyebarkan skala resiliensi untuk mengukur tingkat resiliensi siswa. Selanjutnya subjek calon pengguna produk yaitu konselor di SMP Negeri 04 
Kota Batu. Pada penelitian pengembang ini, peneliti menggunakan instrumen penelitian berupa (1) skala resiliensi kepada siswa dan wawancara mendalam kepada konselor untuk menganalisiss kebutuhan dan potensi masalah (2) instrumen penilaian kelayakan produk untuk uji ahli dan calon pengguna produk.

Selanjutnya hasil pengumpulan data akan dikembangkan menjadi rumusan masalah serta tujuan dalam mengembangkan produk penelitian. Pengembangan ini bertujuan untuk membuat produk paket bimbingan yang dapat digunakan konselor untuk memberikan layanan bimbingan mengenai resiliensi. Analisiss dalam pengembangan ini dilakukan dengan metode analisiss deskriptif yang berguna untuk memberikan penilaian atau interpretasi sesuai kriteria keberterimaan produk (ketepatan, kemudahan, kegunaan dan kemenarikan). Selain itu peneliti juga menganalisiss data kuantitatif dalam penelitian ini. Data kuantitatif merupakan data yang diperoleh dari hasil uji calon pengguna produk. Bentuk data kuantitatif ini berupa angka atau skor penilaian yang diberikan oleh ahli melalui angket penilaian yang disediakan oleh peneliti. Data saran dan komentar ahli digunakan untuk membantu dalam proses revisi produk akhir

\section{Hasil dan Pembahasan}

\subsection{Hasil}

Hasil dari penelitian pengembangan ini berupa produk paket pelatihan bimbingan dengan teknik outbound untuk mengembangkan resiliensi pada siswa SMP. Pada produk paket ini terdapat buku panduan untuk konselor sebagai acuan saat melaksanakan bimbingan.

Tabel 1. Hasil Penilaian Uji Ahli Bimbingan dan Konseling

\begin{tabular}{|c|c|c|}
\hline No & Komentar & Saran \\
\hline 1 & Judul kurang tepat & $\begin{array}{l}\text { Judul sebaiknya ditambahkan "Panduan Paket } \\
\text { Pengembangan dan sebaiknya pengembangan } \\
\text { resiliensi siswa, bukan peningkatan resiliensi siswa } \\
\text { karena ini bimbingan bukan konseling }\end{array}$ \\
\hline 2 & Cover buku panduan & $\begin{array}{l}\text { Ganti gambar di cover dengan yang lebih } \\
\text { mencerminkan resensi }\end{array}$ \\
\hline 3. & Ukuran huruf terlalu kecil & $\begin{array}{l}\text { Mengganti ukuran huruf / jenis huruf yang lebih } \\
\text { tebal dan besar }\end{array}$ \\
\hline 4. & Sasaran pada buku panduan & Sasaran hanya untuk konselor tidak perlu siswa \\
\hline 5. & $\begin{array}{l}\text { Alokasi waktu pertemuan } \\
\text { kurang logis dan kegiatan } \\
\text { refleksi harus mendapatkan } \\
\text { porsi waktu yang cukup }\end{array}$ & $\begin{array}{l}\text { Dalam } 1 \text { pertemuan maksimal } 2 \text { permainan jadi } \\
\text { dapat dibuat } 4 \mathrm{x} \text { pertemuan }\end{array}$ \\
\hline 6. & $\begin{array}{l}\text { Tidak ada jadwal pelaksanaan } \\
\text { dan instrumen refleksi }\end{array}$ & $\begin{array}{l}\text { Ditambahkan jadwal pelaksanaan dan instrumen } \\
\text { refleksi }\end{array}$ \\
\hline
\end{tabular}


Tabel 2. Hasil Penilaian Uji Ahli Desain Produk

\begin{tabular}{cll}
\hline No & \multicolumn{1}{c}{ Komentar } & \multicolumn{1}{c}{ Saran } \\
\hline 1. & Aspek desain grafis kurang optimal & $\begin{array}{l}\text { Ornamen hias visualisasinya perlu } \\
\text { diminimalis karena mengganggu } \\
\text { viewing pembaca buku }\end{array}$ \\
& & Sebaiknya menggunakan jenis font \\
2 & Jenis font pada teks & yang keterbacaan (readability) tinggi \\
& & Cantumkan "panduan untuk konselor" \\
3 & Cover depan & Sebaiknya gambar / foto yang diambil \\
4 & Gambar yang dikutip tidak ada sumbernya & / dikutip dari pihak lain dicantumkan \\
& & Sumbernya. \\
& & \\
& &
\end{tabular}

Tabel 3. Hasil Penilaian Uji Calon Pengguna Produk

\begin{tabular}{ccc}
\hline No & Komentar & Saran \\
\hline 1. & Instrumen refleksi kurang rinci & Lebih memperinci instrumen refleksi \\
\hline
\end{tabular}

Uji kelayakan produk diperoleh dari hasil materi bimbingan dan konseling, uji ahli desain produk dan uji calon pengguna produk. Hasil rata - rata penilaian uji ahli uji ahli materi bimbingan dan konseling yang didapatkan yaitu 0,88 yang berarti produk memiliki ekuivalen sangat layak untuk digunakan karena memiliki validitas sangat tinggi. Sedangkan hasil penilaian uji ahli bimbingan konseling secara deskriptif disajikan dalam tabel 1.

Selanjutnya hasil rata - rata penilaian uji ahli desain produk yang didapatkan yaitu 0,94 yang berarti produk memiliki ekuivalen sangat layak untuk digunakan karena memiliki validitas sangat tinggi. Sedangkan hasil penilaian uji ahli desain produk secara deskriptif disajikan dalam tabel 2.

Hasil rata - rata penilaian uji calon pengguna produk yaitu Hasil yang didapatkan yaitu 1,00 yang berarti produk memiliki ekuivalen sangat layak untuk digunakan karena memiliki validitas sangat tinggi. Sedangkan hasil penilaian uji calon pengguna produk secara deskriptif disajikan dalam tabel 3.

Dari keseluruhan penilaian uji ahli dan calon pengguna produk dapat disimpulkan bahwa produk sangat layak untuk digunakan sesuai dengan kriteria keberterimaan. Selanjutnya saran dan perbaikan dilakukan peneliti untuk menyempurnakan produk. Dapat dikatakan bahwa produk paket pelatihan bimbingan dengan teknik outbound untuk mengembangkan resiliensi sudah layak digunakan oleh konselor.

\subsection{Pembahasan}

Berdasarkan hasil penilaian yang dipaparkan pada bagian sebelumnya, dapat disimpulkan bahwa produk paket pelatihan bimbingan dengan teknik outbound untuk mengembangkan resiliensi sudah layak digunakan oleh konselor. Hal ini dapat diketahui dari hasil penilaian kelayakan produk oleh uji ahli materi bimbingan dan konseling, uji ahli desain produk dan uji calon pengguna produk. Ketiga uji kelayakan tersebut telah mempertimbangkan empat aspek keberterimaan produk yaitu aspek ketepatan, kegunaan, kemudahan dan kemenarikan. Melalui proses uji kelayakan itulah produk awal diberi masukan 
dan direvisi. Sehingga produk ini dapat digunakan oleh konselor untuk memberi bimbingan terkait resiliensi.

Resiliensi menjadi kemampuan yang harus dimiliki individu untuk mempertahankan diri dari kondisi yang tidak menyenangkan atau kondisi yang sulit, agar menjadi individu yang mampu berkembang secara optimal. Menurut Grotberg (dalam Desmita, 2006) resiliensi sebagai kekuatan atau daya tahan seseorang untuk menghadapi, mengatasi, menjadi lebih kuat, dan bahkan mengubah pengalaman tidak menyenangkan. Individu dengan kepribadian resilien akan merasakan bahwa hidup bermakna, memiliki tujuan, dan penuh harapan. resiliensi adalah kemampuan individu untuk bertahan dalam menghadapi persoalan atau kesulitan sehingga individu dapat menjadi lebih kuat, berkembang, menjadi percaya diri dan mampu melihat hal tersebut sebagai keberuntungan bukan hambatan.

Produk ini dikembangkan berdasarkan analisis kebutuhan dan kajian pustaka yang telah dianalisiss oleh peneliti. Teknik outbound dirasa tepat menjadi teknik yang dapat digunakan untuk mengembangkan resiliensi. Outbound bertujuan membangun kecerdasan kolektif melalui kematangan individu, kemampuan berkoordinasi, kepercayaan antar anggota dan semangat untuk saling mendukung. Dari pelatihan outbound akan mendukung munculnya resiliensi pada diri individu. Menurut Ancok (2002) outbound merupakan suatu penambah wawasan pengetahuan yang didapat dari serangkaian pengalaman berpetualang sehingga dapat memacu semangat dan kreatifitas seseorang. Sehingga paket pelatihan bimbingan yang dikembangkan oleh peneliti memberikan serangkaian kegiatan bimbingan untuk mengembangkan resiliensi secara berkala dari konselor melalui proses bimbingan.

Dalam setiap permainan dalam outbound akan menjadi teknik untuk mengembangkan tiap - tiap faktor pembentuk resiliensi. Teknik outbound menghadirkan situasi dan kondisi nyata pada permainan - permainannya yang memberikan dampak pembelajaran pada aspek kognitif, afektif dan psikomotorik. Menurut Siebert (2005), resiliensi dianggap sebagai kemampuan dalam mengatasi perubahan yang mengganggu. Dalam kondisi tertekan, individu akan mampu mempertahankan energi dan kesehatannya. Selain itu individu akan mampu bangkit kembali dari masalah dan mengatasinya.

Produk pengembangan yang dibuat oleh peneliti terdiri dari tiga bab, yaitu 1) Bab I memaparkan tentang rasional, tujuan, sasaran layanan, metode dan jadwal pelaksanaan bimbingan, 2) Bab II memaparkan tentang petunjuk pelaksanaan dan peran konselor dan siswa dalam bimbingan, 3) Bab III menjelaskan tentang prosedur pelaksanaan melalui rancangan pelaksanaan layanan bimbingan dan konseling (RPLBK). Pembagian tersebut bertujuan agar pengguna memahami paket pelatihan bimbingan dengan baik dan benar. Peneliti mengembangkan paket bimbingan ini dengan komprehensif. Dalam buku ini terdapat serangkaian kegiatan bimbingan secara runtut dan juga dilengkapi uraian materi. Instrumen refleksi juga ditambahkan pada produk ini untuk menyempurnakan produk bimbingan ini. Pada instrumen refleksi, terdapat poin - poin yang dikaitkan dengan tujuh faktor pembentuk resiliensi.

\section{Simpulan}

Kesimpulan yang diperoleh dari produk pengembangan paket pelatihan bimbingan dengan teknik outbound untuk mengembangkan resiliensi adalah produk ini telah memenuhi ke - 4 aspek keberterimaan diantaranya, aspek ketepatan, kegunaan, kemudahan dan 
kemenarikan. Namun untuk mengetahui keefektifan dari paket tersebut, konselor maupun peneliti selanjutnya diperkenankan melakukan uji eksperimen dengan kelompok terbatas

\section{Daftar Rujukan}

Ancok, D. (2002). Outbound Management Training: Aplikasi Ilmu Perilaku dalam Pengembangan Sumber Daya Manusia. Yogyakarta: UII Press

Asti, B. M. (2009). Fun Outbound: Merancang Kegiatan Outbound yang Efektif. Yogyakarta: DIVA Press.

Borg, W. R. \& Gall, M. D. (2003). Educational Research An Introduction (7 th ed.). Boston: Longman

Desmita. (2015). Psikologi Perkembangan. Bandung: Rosda.

Goleman, D. (1998). Working with emotional intelligence. New York: Bantam Books

Grotberg, E. (1995). A guide to promoting resilience in children: strengthening the human spirit. Tersedia pada https://bibalex.org/baifa/Attachment/Documents/115519.pdf

Hurlock, E. B. (2000). Psikologi Perkembangan: Suatu Pendekatan Sepanjang Rentang Kehidupan. Jakarta: Erlangga

Johnson, D. W., \& Johnson, F.P. (2000). Joining Together: Group Theory and Group Skill. Allyn and Bacon, Inc, Tokyo.

Muhammad, A. (2009). The Power of Outbound Training. Yogyakarta: Power Books (IHDINA)

Reivich, K. \& Shatte, A. (2002). The resilience factor: Seven essential skills for overcoming life's inevitable obstacles. New York: Broadway Books

Romlah, T. (2001). Teori dan praktek bimbingan kelompok, Malang: Universitas Negeri Malang

Sugiyono. (2011). Metode Penelitian Kuantitatif, Kualitatif dan $R \& D$. Bandung: Alfabeta

Susanta, A. (2010). Outbound Profesional. Pengertian, Prinsip Perancangan, dan Panduan Pelaksanaan. Yogyakarta: ANDI Yogyakarta

Yuswanto, N. (2008). Outbound Sport. Surabaya: UNESA University Press 